\title{
APLIKASI DAN EFEKTIVITAS PUPUK HAYATI DALAM UPAYA PERBAIKAN MUTU PRODUKSI, PRODUKTIVITAS DAN PENGENDALIAN SERANGAN LAYU FUSARIUM PADA BAWANG MERAH
}

\section{THE APPLICATION AND EFFECTIVITY OF BIOFERTILIZERS TO IMPROVE YIELD, PRODUCTIVITY AND CONTROL FUSARIUM WILT IN SHALLOT}

\author{
Wakiah Nuryani ${ }^{1}{ }^{1}$, Hanudin $^{1)}$ dan Kurniawan Budiarto ${ }^{2)}$ \\ ${ }^{1)}$ Balai Penelitian Tanaman Hias, Jl. Raya Pacet-Ciherang, PO. Box. 8SDL, Pacet, Cianjur, Jawa \\ Barat (43253) \\ ${ }^{2)}$ Balai Penelitian Tanaman Jeruk dan Buah Subtropika, Jl. Raya Tlekung No.1 Junrejo, Kota Batu \\ (65327), Jawa Timur
}

Korespodensi : wnuryani@yahoo.com

Diterima : 16 September 2019 / Disetujui : 2 Juli 2020

\begin{abstract}
ABSTRAK
Bawang merah (Allium ascalonicum $\mathrm{L}$.) merupakan salah satu komoditas sayuran unggulan nasional yang mempunyai nilai ekonomi tinggi. Untuk pencapai target produksi yang maksimal, umumnya petani menggunakan pupuk dan pestisida kimia sintetik yang tinggi. Penurunan daya dukung lahan pertanian akibat penggunaan bahan kimia agroinput berlebihan mendorong penggunaan pupuk hayati berbahan aktif mikroba pemicu pertumbuhan terutama untuk mengurangi penggunaan pupuk kimia sintetik pada bawang merah. Penelitian bertujuan untuk mengevaluasi beberapa pupuk hayatiyang dikombinasikan dengan pupuk kimia sintetik untuk meningkatkan kualitas pertumbuhan dan produksi bawang merah, serta menekan penyakit layu fusarium. Penelitian menggunakan Rancangan Acak Kelompok dengan 3 ulangan. Perlakuan berupa tiga jenis pupuk hayati, yaitu Agrofit, Bio Pf dan Biotrico dikombinasikan dengan dosis pupuk kimia sintetik yaitu sebesar $0,25,50,75,100 \%$ dari dosis rekomendasi. Hasil penelitian menunjukkan bahwa aplikasi kombinasi pupuk hayati Agrofit, Bio-Pf dan Biotrico dengan $50 \%$ dosis rekomendasi pupuk kimia sintetik dapat meningkatkan kualitas pertumbuhan dan bobot umbi kering sebesar 7.91 - 32.65\% dari aplikasi pupuk kimia sintetik $100 \%$ dosis rekomendasi. Pada kombinasi Bio-Pf yang ditambah dengan $25 \%$ pupuk kimia sintetik dosis rekomendasi menunjukkan nilai efektifitas relatif agronomi dan nilai penekanan terhadap infeksi fusarium tertinggi. Kombinasi perlakuan ini juga memberikan total biomasa tidak berbeda pada dosis pupuk kimia sintetik $100 \%$.
\end{abstract}

Kata kunci : Allium ascalonicum L., bobot umbi, efektifitas, Fusarium oxysporum f. sp. cepae (Snyder and Hans.), pupuk hayati

Cyte this as: Nuryani, W., Hanudin \& Budiarto, K. (2020). Aplikasi dan efektivitas pupuk hayati dalam upaya perbaikan mutu produksi, produktivitas dan pengendalian serangan layu fusarium pada bawang merah. Jurnal Agro, 7(1), 52-70. https://doi.org/10.15575/6244 


\begin{abstract}
Shallot is one of important vegetables in Indonesia. Expecting high yield, farmers tend to apply high amount of chemical fertilizer and shynthetic pesticide. The concern to the negative impacts of chemical agroinput in agriculture production has induced the application of biofertilizer containing beneficial microbes to reduce the use of synthetic fertilizers in shallot production. The research was conducted to evaluate several formulated biofertilizers combined with synthetic fertilizers on growth, yield and productivity improvement, and fusarium wilt control on shallot. The research was conducted at Sukabumi, West Java, Indonesia from March to August 2017. The combination of bio-fertilizer types, i.e. Agrofit, Bio$\mathrm{Pf}$ and Biotrico and synthetic fertilizers in different dosages, i.e 0, 25, 50, 75, $100 \%$ from recommended dosages were arranged in completely randomized block design with three replications. The results showed the application of bio-fertilizers might reduce $50 \%$ of synthetic fertilizer usage. The combined application of each bio-fertilizer with 50\% recommended dosage of synthetic fertilizers improved growth quality and total dry bulb weight of $7.91-32.65 \%$ from $100 \%$ recommended dosage of synthetic fertilizer. The combination of Bio-Pf and Agrofit with $25 \%$ recommended synthetic fertilizer gave highest relative agronomic effectiveness value and fusarium wilt suppression. Total biomass weight of these treatments also had negligible differences with $100 \%$ synthetic fertilizers dosages.
\end{abstract}

Keywords: Allium ascalonicum L., bio-fertilizers, bulb weight, effectiveness, Fusarium oxysporum f. sp. cepae (Snyder and Hans).

\section{PENDAHULUAN}

Bawang merah (Allium ascalonicum L.) merupakan salah satu komoditas sayuran unggulan nasional yang mempunyai nilai ekonomi tinggi. Komoditas ini umumnya digunakan sebagai bumbu masak, permintaan bawang merah untuk keperluan tersebut baik dalam bentuk segar dan bibit selalu meningkat setiap tahun (Sumarni et al., 2013). Konsumsi yang tinggi pada komoditas bawang merah hingga saat ini masih belum dapat dipenuhi dari produksi dalam negeri sehubungan dengan pola produksi yang musiman. Kondisi ini sering menyebabkan terjadinya kelangkaan pasokan di beberapa daerah, sehingga menyebabkan gejolak harga yang fluktuatif dan menyumbang inflasi dari sektor pertanian (Setiawan \& Hadianto, 2014).

Bawang merah dapat dibudidayakan pada kisaran agroklimatik yang luas dari dataran rendah hingga tinggi pada lahan bekas sawah/padi, lahan kering dan lahan perkarangan. Keragaman tanah dan lingkungan yang cukup tinggi di Indonesia menyebabkan kebutuhan pupuk berbeda dari satu lokasi ke lokasi lainnya (Istina, 2016; Bunga \& Lewar, 2009). Hingga kini penggunaan pupuk dan pestisida sintetik pada usaha tani bawang merah dilaporkan cukup tinggi dan telah mengakibatkan kerusakan dan daya dukung lahan pertanian di beberapa sentra produksi (Badrudin \& Jazilah, 2013; Miskiyah \& Munarso, 2009; Indrianingsih et al., 2007). Kondisi ini beresiko tidak hanya pada kelangsungan usaha pertanian itu sendiri, namun juga berdampak negatif pada lingkungan dan membahayakan kesehatan manusia (Damayanti, Hanani, \& Yunita, 2016; Harsanti et al., 2015). Kondisi demikian tampaknya tidak dapat dipertahankan lagi, mengingat pemberlakuan ISO 14000 dan era 
Masyarakat Ekonomi ASEAN (MEA) 2015 menuntut jaminan kesehatan selama proses produksi tanaman (Wastra, 2015). Oleh karena itu perlu dicari alternatif lain untuk mengurangi atau bahkan mensubstitusi penggunaan pupuk dan pestisida kimia sintetik melalui teknologi pemupukan yang efektif, efisien dan ramah lingkungan.

Salah satu metode pemupukan yang ramah lingkungan adalah dengan penggunaan pupuk mikrobiologis (pupuk hayati) yang mengandung mikroorganisme menguntungkan sebagai pembenah tanah dan pemicu pertumbuhan dengan meningkatkan pasokan nutrisi untuk tanaman (Gupta et al., 2015). Peningkatan pertumbuhan juga diinduksi oleh mikrob pemicu pertumbuhan yang terkandung dalam pupuk hayati melalui produksi beragam pengatur tumbuh seperti auksin, giberelin dan sitokinin (Ahmed \& Hasnain, 2014; Gupta et al., 2015), menurunkan kadar etilen (Wang et al., 2015) dan fiksasi nitrogen melalui asosiasi akar (Reed et al., 2011). Selain induksi peningkatan pertumbuhan, pupuk hayati juga dilaporkan dapat menekan serangan penyakit dengan memproduksi senyawa antibiosis dan menginduksi ketahanan tanaman terhadap patogen (Beneduzi et al., 2012).

Peran pupuk hayati berbahan aktif mikrob juga diharapkan dapat mengendalikan penyakit layu pada bawang merah yang disebabkan oleh Fusarium oxysporum f. sp. cepae (Snyder and Hans). Penyakit ini merupakan salah satu penyakit utama pada bawang merah (Sintayehu et al., 2013; Kaeni et al., 2014) dan pada serangan tinggi dapat mengakibatkan kehilangan hasil hingga 50\% (Juwanda et al., 2016).
Beberapa pupuk hayati yang mengandung mikroorganisme pemicu pertumbuhan ini telah berhasil diformulasi dan telah dikomersialisasikan. Bio Pf diformulasi oleh Balai Penelitian Tanaman Hias dengan bahan aktif meliputi Pseudomonas fluorescens, Azotobacter sp., and Azosprillium sp. Biotrico diproduksi oleh Balai Penelitian Tanaman Sayuran dengan bahan aktif meliputi Trichoderma sp. Agrofit diproduksi oleh Balai Penelitian Tanah dan teregistrasi mengandung bahan aktif konsorsium bakteri endofotik Aberzotobacter sp. JBN05, Azospirilium sp. KR6, Bacillus sp. KT6D, Candida sp.YBN3 dan ragi. Beberapa formulasi pupuk hayati pemicu pertumbuhan dengan kandungan mikrob yang lainpun telah diproduksi oleh Badan Penelitian dan Pengembangan Pertanian dan telah terbukti dapat meningkatkan produksi, produktifitas serta menurunkan penggunaan input produksi pada usaha tani beberapa tanaman hortikultura (Hanudin \& Marwoto, 2012). Namun demikian, masih sedikit informasi perihal efektifitas pupuk hayati ini pada tanaman bawang merah. Penelitian ini bertujuan menguji beberapa pupuk hayati unggulan yang memberikan respon terbaik terhadap mutu produksi, produktivitas, dan dapat menekan penyakit layu fusarium pada tanaman bawang merah. Implikasi dari hasil pengujian ini diharapkan akan meningkatkan pertumbuhan dan produktivitas bawang merah sekaligus menekan penggunaan pupuk kimia dan pestisida kimia sintetik, sehingga akan menjamin dihasilkannya produk yang berdaya saing tinggi, tidak mengganggu kesehatan pelaku usaha tani dan konsumen serta ramah lingkungan. 


\section{BAHAN DAN METODE}

Penelitian dilaksanakan di lahan petani di Desa Cidadap, Kecamatan Simpenan, Kabupaten Sukabumi, Jawa Barat pada ketinggian $100 \mathrm{mdpl}$ dari bulan Maret hingga Agustus 2017. Lahan tersebut merupakan endemik fusarium dengan intensitas serangan berkisar antara 35-50 \%. Penelitian menggunakan Rancangan Acak Kelompok dengan 3 ulangan. Varietas bawang merah yang digunakan adalah cv. Bima yang didapatkan dari penangkar komersial. Pengujian pupuk hayati terdiri atas 17 perlakuan yang disajikan pada pada Tabel 1 di bawah ini.

Tabel 1. Perlakuan pengujian pupuk hayati pada tanaman bawang merah.

\begin{tabular}{|c|c|c|c|}
\hline No. & Kode & Perlakuan & Deskripsi Perlakuan \\
\hline 1. & Kontrol (-) & Tanpa pupuk & $\begin{array}{l}\text { Tanaman bawang merah tidak diberikan } \\
\text { pupuk dasar dan pupuk kimia sintetik } \\
\text { susulan. }\end{array}$ \\
\hline 2. & Kontrol (+) & $\begin{array}{l}\text { Pupuk dasar dan } \\
\text { kimia sintetik } 100 \% \\
\text { sesuai rekomendasi } \\
\text { budidaya }\end{array}$ & $\begin{array}{l}\text { Pupuk dasar berupa pupuk kandang } \\
\text { sapi/kuda } 20 \text { ton/ha, } \mathrm{SP}-36250 \mathrm{~kg} / \mathrm{ha} \text { dan } \mathrm{KCl} \\
200 \mathrm{~kg} / \mathrm{ha} \text { yang diaplikasikan dengan cara } \\
\text { diaduk rata dengan tanah } 3 \text { hari sebelum } \\
\text { tanam. Pemupukan susulan menggunakan } \\
\text { Urea } 100 \mathrm{~kg} / \mathrm{ha} \text { dan } \mathrm{ZA} 150 \mathrm{~kg} / \mathrm{ha} \text { yang } \\
\text { dilakukan pada umur } 15 \text { dan } 30 \text { hari setelah } \\
\text { tanam (HST). }\end{array}$ \\
\hline 3. & Agrofit & Agrofit 100\% & $\begin{array}{l}\text { Benih umbi bawang merah direndam dalam } \\
\text { air bersih selama } 10 \text { menit kemudian } \\
\text { dicampurkan dengan Agrofit sebelum di } \\
\text { tanam. Sehari sebelum tanam, Agrofit } \\
\text { dengan dosis } 10 \mathrm{~kg} / \mathrm{ha} \text { juga diaplikasikan } \\
\text { dengan cara diaduk dengan tanah bagian } \\
\text { atas bedengan. Tanaman bawang merah } \\
\text { tidak diberikan pupuk dasar dan pupuk kimia } \\
\text { sintetik susulan hingga panen. }\end{array}$ \\
\hline 4. & $\begin{array}{l}\text { Agrofit }+25 \% \\
\text { Kontrol }(+)\end{array}$ & $\begin{array}{l}\text { Agrofit }+ \text { Pupuk } \\
\text { dasar dan kimia } \\
\text { sintetik } 25 \% \text { sesuai } \\
\text { rekomendasi } \\
\text { budidaya }\end{array}$ & $\begin{array}{l}\text { Benih umbi bawang merah dan bedengan } \\
\text { diperlakukan dengan Agrofit seperti } \\
\text { perlakuan Agrofit } 100 \% \text {. Benih dan lahan } \\
\text { bedengan diberi pupuk dasar (organik }+ \\
\text { kimia sintetik) dan pupuk susulan kimia } \\
\text { sintetik } 25 \% \text { dari dosis yang } \\
\text { direkomendasikan. }\end{array}$ \\
\hline 5. & $\begin{array}{l}\text { Agrofit }+50 \% \\
\text { Kontrol }(+)\end{array}$ & $\begin{array}{l}\text { Agrofit }+ \text { Pupuk } \\
\text { dasar dan kimia } \\
\text { sintetik } 50 \% \text { sesuai } \\
\text { rekomendasi } \\
\text { budidaya }\end{array}$ & $\begin{array}{l}\text { Benih umbi bawang merah dan bedengan } \\
\text { diperlakukan dengan Agrofit seperti } \\
\text { perlakuan Agrofit } 100 \% \text {. Benih dan lahan } \\
\text { bedengan diberi pupuk dasar (organik + } \\
\text { kimia sintetik) dan pupuk susulan kimia } \\
\begin{array}{l}\text { sintetik } 50 \% \text { dari dosis yang } \\
\text { direkomendasikan. }\end{array}\end{array}$ \\
\hline 6. & $\begin{array}{l}\text { Agrofit }+75 \% \\
\text { Kontrol (+) }\end{array}$ & $\begin{array}{lcr}\text { Agrofit } & + & \text { Pupuk } \\
\text { dasar dan } & \text { kimia } \\
\text { sintetik } & 50 \% & \text { sesuai }\end{array}$ & $\begin{array}{l}\text { Benih umbi bawang merah dan bedengan } \\
\text { diperlakukan dengan Agrofit seperti } \\
\text { perlakuan Agrofit } 100 \% \text { ditambah dengan }\end{array}$ \\
\hline
\end{tabular}




\begin{tabular}{|c|c|c|c|}
\hline & & $\begin{array}{l}\text { rekomendasi } \\
\text { budidaya }\end{array}$ & $\begin{array}{l}\text { pemberian pupuk dasar (organik }+ \text { kimia } \\
\text { sintetik) dan pupuk susulan kimia sintetik } \\
75 \% \text { dari dosis yang direkomendasikan. }\end{array}$ \\
\hline 7. & $\begin{array}{l}\text { Agrofit + 100\% } \\
\text { Kontrol (+) }\end{array}$ & $\begin{array}{l}\text { Agrofit }+ \text { Pupuk } \\
\text { dasar dan kimia } \\
\text { sintetik sesuai } \\
\text { rekomendasi } \\
\text { budidaya }\end{array}$ & $\begin{array}{l}\text { Benih umbi bawang merah dan bedengan } \\
\text { diperlakukan dengan Agrofit seperti } \\
\text { perlakuan Agrofit } 100 \% \text { ditambah dengan } \\
\text { pemberian pupuk dasar (organik + kimia } \\
\text { sintetik) dan pupuk susulan kimia sintetik } \\
100 \% \text { dari dosis yang direkomendasikan. }\end{array}$ \\
\hline 8. & Bio Pf & Bio Pf $100 \%$ & $\begin{array}{l}\text { Benih umbi bawang merah direndam dalam } \\
\text { larutan Bio Pf } 1 \% \text { selama } 20 \text { menit sebelum } \\
\text { tanam. Lahan bedengan kemudian dikocor } \\
\text { dengan konsentrasi yang sama pada } 15 \text { dan } \\
30 \text { HST. Tanaman bawang merah tidak } \\
\text { diberikan pupuk dasar dan pupuk kimia } \\
\text { sintetik susulan hingga panen. }\end{array}$ \\
\hline 9. & $\begin{array}{l}\text { Bio Pf }+25 \% \\
\text { Kontrol }(+)\end{array}$ & $\begin{array}{l}\text { Bio Pf }+ \text { Pupuk } \\
\text { dasar dan kimia } \\
\text { sintetik } 25 \% \text { sesuai } \\
\text { rekomendasi } \\
\text { budidaya }\end{array}$ & $\begin{array}{l}\text { Benih umbi bawang merah dan bedengan } \\
\text { diperlakukan dengan Bio Pf sepertiperlakuan } \\
\text { Bio Pf } 100 \% \text {. Benih dan lahan bedengan } \\
\text { diberi pupuk dasar (organik + kimia sintetik) } \\
\text { dan pupuk susulan kimia sintetik } 25 \% \text { dari } \\
\text { dosis yang direkomendasikan. }\end{array}$ \\
\hline 10. & $\begin{array}{l}\text { Bio Pf }+50 \% \\
\text { Kontrol }(+)\end{array}$ & $\begin{array}{l}\text { Bio Pf }+ \text { Pupuk } \\
\text { dasar dan kimia } \\
\text { sintetik } 50 \% \text { sesuai } \\
\text { rekomendasi } \\
\text { budidaya }\end{array}$ & $\begin{array}{l}\text { Benih umbi bawang merah dan bedengan } \\
\text { diperlakukan dengan Bio Pf sepertiperlakuan } \\
\text { Bio Pf } 100 \% \text {. Benih dan lahan bedengan } \\
\text { diberi pupuk dasar (organik + kimia sintetik) } \\
\text { dan pupuk susulan kimia sintetik } 50 \% \text { dari } \\
\text { dosis yang direkomendasikan. }\end{array}$ \\
\hline 11. & $\begin{array}{l}\text { Bio Pf }+75 \% \\
\text { Kontrol }(+)\end{array}$ & $\begin{array}{l}\text { Bio Pf }+ \text { Pupuk } \\
\text { dasar dan kimia } \\
\text { sintetik } 75 \% \text { sesuai } \\
\text { rekomendasi } \\
\text { budidaya }\end{array}$ & $\begin{array}{l}\text { Benih umbi bawang merah dan bedengan } \\
\text { diperlakukan dengan Bio Pf sepertiperlakuan } \\
\text { Bio Pf } 100 \% \text {. Benih dan lahan bedengan } \\
\text { diberi pupuk dasar (organik + kimia sintetik) } \\
\text { dan pupuk susulan kimia sintetik } 75 \% \text { dari } \\
\text { dosis yang direkomendasikan. }\end{array}$ \\
\hline 12. & $\begin{array}{l}\text { Bio Pf }+100 \% \\
\text { Kontrol }(+)\end{array}$ & $\begin{array}{l}\text { Bio Pf }+ \text { Pupuk } \\
\text { dasar dan kimia } \\
\text { sintetik } 100 \% \text { sesuai } \\
\text { rekomendasi } \\
\text { budidaya }\end{array}$ & $\begin{array}{l}\text { Benih umbi bawang merah dan bedengan } \\
\text { diperlakukan dengan Bio Pf sepertiperlakuan } \\
\text { Bio Pf } 100 \% \text {. Benih dan lahan bedengan } \\
\text { diberi pupuk dasar (organik + kimia sintetik) } \\
\text { dan pupuk susulan kimia sintetik } 100 \% \text { dari } \\
\text { dosis yang direkomendasikan. }\end{array}$ \\
\hline 13. & Biotrico & Biotrico $100 \%$ & $\begin{array}{l}\text { Biotrico dengan dosis } 50 \mathrm{~kg} / \mathrm{ha} \text { diberikan } 3 \\
\text { hari sebelum tanam. Tanaman bawang } \\
\text { merah tidak diberikan pupuk dasar dan } \\
\text { pupuk kimia sintetik susulan hingga panen. }\end{array}$ \\
\hline 14. & $\begin{array}{l}\text { Biotrico + 25\% } \\
\text { Kontrol (+) }\end{array}$ & $\begin{array}{l}\text { Biotrico }+ \text { Pupuk } \\
\text { dasar dan kimia } \\
\text { sintetik } 25 \% \text { sesuai } \\
\text { rekomendasi } \\
\text { budidaya }\end{array}$ & $\begin{array}{l}\text { Bedengan pertanaman diperlakukan dengan } \\
\text { Biotrico seperti perlakuan Biotrico } 100 \% \text {. } \\
\text { Benih dan lahan bedengan diberi pupuk } \\
\text { dasar (organik + kimia sintetik) dan pupuk } \\
\text { susulan kimia sintetik } 25 \% \text { dari dosis yang }\end{array}$ \\
\hline
\end{tabular}




\begin{tabular}{|c|c|c|c|}
\hline & & & direkomendasikan. \\
\hline 15. & $\begin{array}{l}\text { Biotrico + 50\% } \\
\text { Kontrol (+) }\end{array}$ & $\begin{array}{l}\text { Biotrico }+ \text { Pupuk } \\
\text { dasar dan kimia } \\
\text { sintetik } 50 \% \text { sesuai } \\
\text { rekomendasi } \\
\text { budidaya }\end{array}$ & $\begin{array}{l}\text { Bedengan pertanaman diperlakukan dengan } \\
\text { Biotrico seperti perlakuan Biotrico } 100 \% \text {. } \\
\text { Benih dan lahan bedengan diberi pupuk } \\
\text { dasar (organik }+ \text { kimia sintetik) dan pupuk } \\
\text { susulan kimia sintetik } 50 \% \text { dari dosis yang } \\
\text { direkomendasikan. }\end{array}$ \\
\hline 16. & $\begin{array}{l}\text { Biotrico + 75\% } \\
\text { Kontrol (+) }\end{array}$ & $\begin{array}{l}\text { Biotrico }+ \text { Pupuk } \\
\text { dasar dan kimia } \\
\text { sintetik } 75 \% \text { sesuai } \\
\text { rekomendasi } \\
\text { budidaya }\end{array}$ & $\begin{array}{l}\text { Bedengan pertanaman diperlakukan dengan } \\
\text { Biotrico seperti perlakuan Biotrico } 100 \% \text {. } \\
\text { Benih dan lahan bedengan diberi pupuk } \\
\text { dasar (organik + kimia sintetik) dan pupuk } \\
\text { susulan kimia sintetik } 75 \% \text { dari dosis yang } \\
\text { direkomendasikan. }\end{array}$ \\
\hline 17. & $\begin{array}{l}\text { Biotrico } \quad+ \\
100 \% \text { Kontrol } \\
(+)\end{array}$ & $\begin{array}{l}\text { Biotrico }+ \text { Pupuk } \\
\text { dasar dan kimia } \\
\text { sintetik } 100 \% \text { sesuai } \\
\text { rekomendasi } \\
\text { budidaya }\end{array}$ & $\begin{array}{l}\text { Bedengan pertanaman diperlakukan dengan } \\
\text { Biotrico seperti perlakuan Biotrico } 100 \% \text {. } \\
\text { Benih dan lahan bedengan diberi pupuk } \\
\text { dasar (organik + kimia sintetik) dan pupuk } \\
\text { susulan kimia sintetik } 100 \% \text { dari dosis yang } \\
\text { direkomendasikan. }\end{array}$ \\
\hline
\end{tabular}

\section{Persiapan lahan, pembuatan bedengan dan penanaman}

Lahan diolah dengan cara dicangkul sedalam $\pm 30 \mathrm{~cm}$ dan pada waktu bersamaan, gulma beserta sisa tanaman dibersihkan kemudian dibuang keluar areal penelitian. Bedengan dibuat dengan ukuran $1.1 \times 12 \mathrm{~m}$ dengan ketinggian 40 $\mathrm{cm}$. Sebelum ditanam, pupuk dasar (pupuk organik + kima sintetik) diberikan sesuai dengan desain perlakuan yang ditentukan. Lahan pertanaman digenangi air selama satu malam sebelum benih ditanam. Benih bawang merah ditanam dengan jarak $15 x$ $20 \mathrm{~cm}$, sehingga populasi tanaman per petak adalah 650 siung tanaman.

\section{Pemeliharaan tanaman dan panen}

Penyiraman dilakukan setiap hari saat pagi atau sore hari hingga menjelang panen. Pengendalian gulma dilakukan secara mekanis dan dilakukan pada 20 dan 45 HST. Pengendalian hama dan penyakit menggunakan insektisida abamektin benzoat $30 \mathrm{~g} / \mathrm{l}$ dan lufenuron $50 \mathrm{~g} / \mathrm{l}$ dengan frekuensi sesuai rekomendasi dalam kemasan. Pemupukan susulan disesuaikan dengan perlakuan penelitian yang ditentukan. Panen umbi bawang dilakukan setelah tanaman berumur 70 HST dengan tanda-tanda berupa leher batang telah melunak, tanaman rebah dan daun telah menguning. Bawang merah yang dipanen diikat pada batangnya untuk mempermudah penanganan, umbi dijemur selama 12 hari. Parameter yang diamati meliputi : Pertumbuhan tanaman (tinggi tanaman, jumlah anakan dan jumlah daun); jumlah tanaman yang terserang penyakit layu fusarium; dan hasil umbi (basah dan kering). Pengamatan peubah pertumbuhan tanaman diamati pada 42 HST: sedangkan pengamatan hasil umbi diamati pada saat panen (54 HST) dan bobot umbi kering diamati setelah umbi basah dijemur setelah 7 hari. Pengamatan Intensitas serangan penyakit dihitung dengan rumus mengadopsi metode Nugroho et al. (2015) sebagai berikut:

$$
I=\frac{\sum(n \times v)}{N \times V} \times 100 \%
$$


dimana:

I = indeks gejala serangan;

$\mathrm{N}=$ jumlah tanaman yang diamati sesuai dengan indeks penyakit ke -i;

$\mathrm{n}=$ jumlah tanaman pada sekala tertentu;

$\mathrm{V}=$ nilai skala keparahan tertinggi;

$\mathrm{v}=$ nilai skala tertentu.

Nilai skala keparahan penyakit ditentukan mulai dari 0 sampai dengan 5 , dimana $0=$ tanpa gejala, 1 = Sebagian daun layu dan menguning tetapibelum layu, 2 = sebagian daun kering tetapi belum layu, 3 = tanaman layu tetapi belum busuk, 4 = umbi busuk, 5 = Tanaman mati. Pengujian pengaruh perlakuan dilakukan dengan analisis varian dan uji beda antar perlakuan dengan menggunakan uji DMRT pada selang kepercayaan 95\%.

$\begin{array}{crr}\text { Penilaian } & \text { efektifitas } & \text { secara } \\ \text { teknis/agronomis } & \text { dilakukan } & \text { dengan } \\ \text { perhitungan Nilai } & \text { Efektifitas } & \text { Relatif }\end{array}$

Agronomi (Relative Agronomic Effectiveness/RAE) dengan rumus sesuai Permentan

No.

70/Permentan/SR.140/2011 tahun 25 Oktober 2011 yaitu :

RAE $=\frac{\text { Nilai parameter perlakuan }- \text { Nilai parameter kontrol }}{\text { Nilai parameter standar }- \text { Nilai parameter kontrol }} 100 \%$

Penilaian RAE :

- Nilai RAE $\leq 100 \%$ berarti perlakuan pupuk hayati tidak lebih efektif dari perlakuan standar

- Nilai RAE > 100\% berarti perlakuan pupuk hayati lebih efektif dari perlakuan standar

\section{HASIL DAN PEMBAHASAN}

Pengaruh pupuk hayati terhadap
pertumbuhan tanaman
Perlakuan pupuk kimia sintetik dan
berbagai pupuk hayati memberikan
pengaruh yang berbeda pada

pertumbuhan vegetatif bawang merah hingga 42 HST (Tabel 2). Tanaman bawang merah yang tidak diberi pupuk (kontrol (-)) memperlihatkan nilai tinggi tanaman, jumlah anakan dan jumlah daun terendah diantara perlakuan pupuk hayati. Tanaman bawang merah yang diberi perlakuan pemupukan kimia sintetik $100 \%$ sesuai rekomendasi budidaya (kontrol (+), perlakuan tunggal Agrofit, Bio Pf serta Biotrico menunjukkan tinggi tanaman, jumlah anakan dan jumlah daun lebih tinggi walaupun tidak berbeda nyata dibandingkan dengan kontrol (-).Data pada Tabel 2 juga menunjukkan bahwa perlakuan Agrofit dan Bio Pf yang dikombinasikan dengan perlakuan pupuk kimia sintetik dengan dosis 50 dan 100\% dari rekomendasi memberikan peningkatan pertumbuhan sebesar 45,5$58 \%$ pada tinggi tanaman, jumlah anakan sebesar 29,9-46,4\% dan jumlah daun sebesar 68,5-81,2\%. Sedangkan perlakuan Biotrico yang dikombinasikan dengan berbagai dosis pupuk kimia sintetik hanya memberikan pengaruh positif pada tinggi tanaman dan jumlah anakan, namun tidak pada jumlah daun. Pupuk hayati yang mengandung berbagai jenis mikrob menguntungkan seperti pada Bio Pf dan Agrofit diduga memberikan kondisi pertumbuhan yang lebih baik, dibandingkan Biotrico yang mempunyai kandungan mikrob tunggal. Mikrob-mikrob menguntungkan ini dapat bertindak secara simultan dalam meningkatkan ketersediaan unsur hara bagi tanaman (Ahemad \& Kibret, 2014), sebagai stimulator pertumbuhan dengan memproduksi hormon pertumbuhan (Vejan et al., 2016; Damam, Kaloori, Gaddam, \& Kausar, 2016), dekomposer bahan organik (Khosravi et al., 2018; 
Gopinathan \& Prakash, 2014 ; Das \& Singh, 2014), dan membantu menekan serangan penyakit dengan memproduksi senyawa antibiotik (Das et al., 2013; Le Mire et al., 2016).

Tabel 2. Perlakuan pupuk hayati terhadap $\mathrm{t}$ tinggi tanaman, jumlah anakan dan jumlah daun bawang merah pada 42 HST.

\begin{tabular}{|c|c|c|c|c|c|c|}
\hline \multirow[b]{2}{*}{ Perlakuan } & \multicolumn{2}{|c|}{ Tinggi tanaman } & \multicolumn{2}{|c|}{ Jumlah anakan } & \multicolumn{2}{|c|}{ Jumlah daun } \\
\hline & Nilai $^{*}$ & $\begin{array}{c}\text { Peningkatan } \\
\text { (\%) }\end{array}$ & Nilai*) & $\begin{array}{c}\text { Peningkatan } \\
\text { (\%) }\end{array}$ & Nilai* $^{*}$ & $\begin{array}{c}\text { Peningkatan } \\
\text { (\%) }\end{array}$ \\
\hline Kontrol (-) & 25.43 a & - & $4.87 \mathrm{a}$ & - & $17.33 \mathrm{a}$ & - \\
\hline Kontrol (+) & 34.99 a & 37.59 & $5.80 \mathrm{ab}$ & 20.00 & $28.33 \mathrm{a}$ & 63.47 \\
\hline Agrofit & $26.88 \mathrm{a}$ & 5.70 & $5.53 \mathrm{a}$ & 13.55 & $22.93 \mathrm{a}$ & 32.31 \\
\hline Agrofit $+25 \%$ Kontrol (+) & $36.94 \mathrm{~b}$ & 45.26 & 5.73 a & 17.66 & $\begin{array}{l}24.80 \\
a b\end{array}$ & 43.10 \\
\hline Agrofit $+50 \%$ Kontrol (+) & $37.63 \mathrm{~b}$ & 47.97 & $6.33 \mathrm{~b}$ & 29.98 & $31.40 \mathrm{~b}$ & 81.19 \\
\hline Agrofit + 75\% Kontrol (+) & $41.57 \mathrm{~b}$ & 63.47 & $5.73 \mathrm{a}$ & 17.66 & $30.33 \mathrm{~b}$ & 75.01 \\
\hline Agrofit $+100 \%$ Kontrol $(+)$ & $38.67 \mathrm{~b}$ & 52.06 & $7.13 \mathrm{~b}$ & 46.41 & $29.53 \mathrm{~b}$ & 70.40 \\
\hline Bio Pf & $29.03 \mathrm{a}$ & 14.16 & $5.33 \mathrm{a}$ & 9.45 & $21.87 \mathrm{a}$ & 26.20 \\
\hline Bio Pf $+25 \%$ Kontrol (+) & $34.95 \mathrm{a}$ & 37.44 & $6.67 \mathrm{~b}$ & 36.96 & $29.40 \mathrm{~b}$ & 69.65 \\
\hline Bio Pf $+50 \%$ Kontrol (+) & $37.00 \mathrm{~b}$ & 58.00 & $6.67 \mathrm{~b}$ & 36.96 & $30.87 \mathrm{~b}$ & 78.13 \\
\hline Bio Pf + 75\% Kontrol (+) & $41.20 \mathrm{~b}$ & 62.01 & $5.60 \mathrm{a}$ & 14.99 & $30.87 \mathrm{~b}$ & 78.13 \\
\hline Bio Pf $+100 \%$ Kontrol (+) & $39.95 b$ & 45.50 & $6.47 \mathrm{~b}$ & 32.85 & $29.20 \mathrm{~b}$ & 68.49 \\
\hline Biotrico & 28.34 a & 11.44 & $4.60 \mathrm{a}$ & -5.54 & $18.27 \mathrm{a}$ & 5.42 \\
\hline Biotrico $+25 \%$ Kontrol (+) & $36.65 a b$ & 44.12 & $6.53 \mathrm{~b}$ & 34.09 & $27.20 \mathrm{a}$ & 56.95 \\
\hline Biotrico $+50 \%$ Kontrol $(+)$ & $40.99 \mathrm{~b}$ & 61.19 & $6.53 \mathrm{~b}$ & 34.09 & $31.80 \mathrm{a}$ & 83.50 \\
\hline Biotrico + 75\% Kontrol (+) & $38.88 \mathrm{~b}$ & 52.89 & $5.53 \mathrm{a}$ & 13.55 & $27.40 \mathrm{a}$ & 58.11 \\
\hline $\begin{array}{l}\text { Biotrico }+100 \% \text { Kontrol } \\
(+)\end{array}$ & $43.67 \mathrm{~b}$ & 71.73 & $6.73 \mathrm{~b}$ & 38.19 & $31.60 \mathrm{a}$ & 82.34 \\
\hline KK (\%) & 27.54 & & 27.37 & & 21.47 & \\
\hline
\end{tabular}

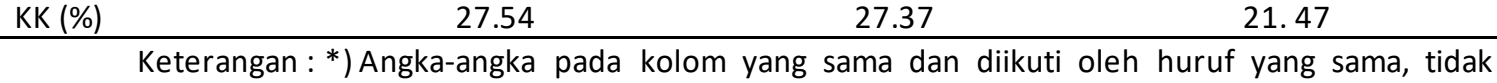
berbeda menurut uji DMRT dengan selang kepercayaan $95 \%$.

Pemberian pupuk hayati yang dikombinasikan dengan pupuk sintetik dosis $25 \%$ dari rekomendasi, memberikan peningkatan pertumbuhan yang tidak merata pada semua parameter pertumbuhan yang diamati. Peningkatan tinggi tanaman, jumlah anakan dan jumlah daun secara signifikan terdeteksi hanya pada tanaman yang diberi perlakuan Agrofit dan Bio Pf yang dikombinasikan dengan perlakuan pupuk kimia sintetik dengan dosis 50 dan 100\% dari rekomendasi (Tabel 2). Hal ini mengindikasikan bahwa mikrob yang terkandung dalam pupuk hayati memerlukan tenggang waktu tertentu untuk dapat memberikan efek pemicu pertumbuhan terhadap tanaman. Tenggang waktu ini diperlukan mikrob menguntungkan dapat mengakuisisi ruang (Vacheron et al., 2013) dan beradaptasi secara ekologis pada lingkungan tumbuh tanaman (Ortega et al., 2017) dan berinteraksi dengan tanaman (Compant et al., 2010) bawang merah. Pada kondisi ini, pupuk kimia sintetik sebesar $50 \%$ dari dosis rekomendasi dapat menstimulir pertumbuhan tanaman terutama awal pertumbuhan, sehingga memberikan tenggang waktu mikrob pupuk hayati untuk dapat berinteraksi dan menstimulasi 
pertumbuhan tanaman lebih optimal dibandingkan kontrol (-) dan (+).

\section{Pengaruh pupuk hayati terhadap serangan fusarium pada umbi bawang merah}

Serangan penyakit layu fusarium pada tanaman bawang merah ditunjukkan oleh batang semu dan daun tumbuh tidak sempurna, yaitu melintir kekiri atau kekanan yang diikuti dengan pemucatan warna daun, tetapi tidak layu (Gambar 1). Hal tersebut disebabkan oleh F. oxysporum f. sp. cepae berkembang biak dan mengkolonisasi sistem perakaran, kemudian memparasit dan menghambat proses pengangkutan air serta hasil fotosintat ke seluruh bagian tanaman. Cendawan patogen Fusarium mengeluarkan mikotoksin dan famoniris yang dapat mengubah flesibilitas selaput plasma pada daun bawang merah yang berakibat daun melintir ke kiri atau ke kanan (Prakoso et al., 2016). Bila patogen sudah melakukan penetrasi dan menginvasi bagian umbi, penghambatan pertumbuhan akan semakin signifikan dan dapat mengakibatkan kematian tanaman (Vivero, 2009).

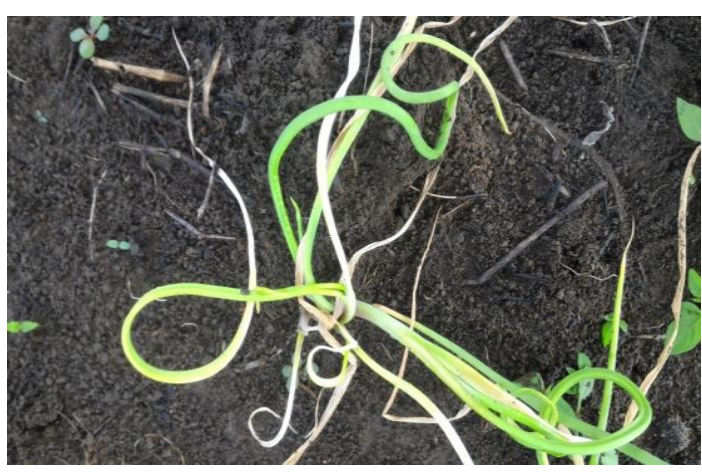

Gambar 1. Gejala serangan F. oxysporum f.sp. cepae pada tanaman bawang merah
Data pada Tabel 3 menunjukkan bahwa serangan penyakit layu Fusarium pada tanaman bawang merah bervariasi, bergantung pada keefektifansetiap perlakuan. Intensitas serangan patogen tersebut berkisar antara 11,16 hingga 35,33\%; dengan kehilangan hasil antara 0,33 dan 1,01 $\mathrm{t} \mathrm{ha}^{-1}$. Dua perlakuan yaitu : Agrofit $+25 \%$ Kontrol (+), dan Bio Pf $+25 \%$ Kontrol (+), menunjukkan perlakuan yang paling efektif dan efisien dalam menekan serangan penyakit layu fusarium pada umbi bawang merah. Hal tersebut ditunjukkan oleh rendahnya intensitas serangan dan kehilangan hasil panen serta tingginya persentase penekanan perlakuan tersebut bila dibandingkan dengan perlakuan lainnya. Intensitas serangan, kehilangan hasil panen dan persentase penekanan akibat perlakuan tersebut masing-masing adalah $11,16 \% ; 0,33 \mathrm{t} \mathrm{ha}^{-1}$; dan 67,33-68,41\% (Tabel 3). Rendahnya kehilangan hasil akibat serangan fusarium pada kedua perlakuan tersebut diduga dipengaruhi oleh terjadinya mekanisme kolonisasi dan antibiosis oleh bahan aktif dari pupuk hayati tersebut. Bio PF dan Agrofit berbahan aktif PGPR (Bacillus sp. dan Pseudomans fluorescens). Mekanis me kolonisasi tersebut berupa bahan eksudat yang terdiri atas asam amino, asam organik, vitamin, alkaloid, substansifenolik, dan unsur anorganik seperti kalium, kalsium, magnesium, dan mangan yang dapat dimanfaatkan untuk pertumbuhan dan perkembangan, sehingga kesempatan spora patogen memanfaatkan eksudat tersebut untuk perkecambahan, infeksi, dan perkembangannya menjadi berkurang (Chaudhry etal., 2016).

Berbagai jenis antibiotik diproduksi oleh P. fluorescens seperti pyuloteorin, oomycin, phenazine-1-carboxylic acid atau 
2,4-diphloroglucinol. Produksi antibiotik ini telah dibuktikan sebagai faktor utama dalam penghambatan perkembangan populasi dan penyakit yang ditimbulkan oleh Phytopthora infetans pada kentang (Roquigny et al., 2018). R. solanacearum dan Plasmodiophora brassicae pada tanaman tomat dan caisin (Hanudin \& Marwoto, 2003), F. oxysporum f. sp. dianthi pada tanaman anyelir (Hanudin, 2007a) dan Xanthomonas campestris pv. dieffenbachiae pada tanaman anthurium (Hanudin, 2007b). Di samping mampu menekan perkembangan populasi dan aktivitas patogen tanaman, $P$. fluorescens juga dapat menginduksi ketahanan tanaman terhadap penyakit.

Tabel 3. Formulasi pupuk hayati terhadap intensitas serangan F. oxysporum f. sp. cepae pada tanaman dan umbi bawang merah.

\begin{tabular}{|c|c|c|c|c|}
\hline Perlakuan & $\begin{array}{c}\text { Intensitas } \\
\text { serangan } \\
\text { fusarium pada } \\
\text { tanaman bawang } \\
\text { merah (\%) }\end{array}$ & $\begin{array}{l}\text { Penekanan } \\
\text { perlakuan } \\
\text { terhadap kontrol } \\
\text { (\%) }\end{array}$ & $\begin{array}{l}\text { Biomasa bawang } \\
\text { merah yang } \\
\text { terinfeksi } \\
\text { fusarium } \\
\text { (t/ha) }\end{array}$ & $\begin{array}{l}\text { Penekanan } \\
\text { perlakuan } \\
\text { terhadap kontrol } \\
\text { (\%) }\end{array}$ \\
\hline Kontrol (-) & $35,33 \mathrm{a}$ & 0 & $1.01 \mathrm{a}$ & 0 \\
\hline Kontrol (+) & $15,89 \mathrm{~b}$ & 55,24 & $0.45 b$ & 55.45 \\
\hline Agrofit & 13,43 b & 61,98 & $0.38 \mathrm{~b}$ & 62.38 \\
\hline Agrofit $+25 \%$ Kontrol (+) & $11,16 b$ & 68,41 & $0.33 \mathrm{~b}$ & 67.33 \\
\hline Agrofit $+50 \%$ Kontrol (+) & $18,72 \mathrm{a}$ & 47,01 & $0.53 a$ & 47.52 \\
\hline Agrofit + 75\% Kontrol (+) & 18,72 a & 47,01 & $0.53 \mathrm{a}$ & 47.52 \\
\hline Agrofit + $100 \%$ Kontrol (+) & 18,72 a & 47,01 & $0.53 \mathrm{a}$ & 47.52 \\
\hline Bio Pf & $15,20 \mathrm{~b}$ & 56,98 & $0.43 b$ & 57.43 \\
\hline Bio Pf + $25 \%$ Kontrol (+) & $11,16 \mathrm{~b}$ & 68,41 & $0.33 \mathrm{~b}$ & 67.33 \\
\hline Bio Pf + 50\% Kontrol (+) & 22,26 a & 37,00 & $0.63 a$ & 37.62 \\
\hline Bio Pf + 75\% Kontrol (+) & 35,00 a & 0,93 & $1.00 \mathrm{a}$ & 0.99 \\
\hline Bio Pf $+100 \%$ Kontrol (+) & 26,85 a & 24,00 & $0.76 a$ & 24.75 \\
\hline Biotrico & $12,72 \mathrm{~b}$ & 64,01 & $0.36 \mathrm{~b}$ & 64.66 \\
\hline Biotrico + 25\% Kontrol (+) & 23,32 a & 33,99 & $0.66 a$ & 34.65 \\
\hline Biotrico + 50\% Kontrol (+) & $18,02 a b$ & 49,01 & $0.51 \mathrm{ab}$ & 49.50 \\
\hline Biotrico + 75\% Kontrol (+) & 25,79 a & 27,00 & $0.73 \mathrm{a}$ & 27.72 \\
\hline Biotrico $+100 \%$ Kontrol $(+)$ & $18,02 a b$ & 48,99 & $0.51 \mathrm{ab}$ & 49.50 \\
\hline KK (\%) & 17,35 & & 19.95 & \\
\hline \multicolumn{5}{|c|}{$\begin{array}{c}\text { Keterangan : }{ }^{*} \text { ) Angka-angka pada kolom yang sama dan diikuti oleh huruf yang sama, tidak } \\
\text { berbeda menurut uji DMRT dengan selang kepercayaan } 95 \%\end{array}$} \\
\hline \multicolumn{2}{|c|}{$\begin{array}{l}\text { Pengaruh pupuk hayati terhadap hasil } \\
\text { umbi bawang merah }\end{array}$} & \multicolumn{3}{|c|}{$\begin{array}{l}\text { hayati (kontrol (-) menghasilkan bobot } \\
\text { umbi basah dan umbi kering terendah dari } \\
\text { semua perlakuan pupuk yang dicoba. Nilai }\end{array}$} \\
\hline \multicolumn{2}{|c|}{$\begin{array}{l}\text { Hasil umbi bawang merah sehat } \\
\text { bervariasi pada berbagai perlakuan pupuk } \\
\text { kimia sintetik dan pupuk hayati (Tabel } 4 \text { ). } \\
\text { Tanaman bawang merah yang tidak diberi } \\
\text { perlakuan pupuk kimia sintetik maupun }\end{array}$} & $\begin{array}{l}\text { bobot umbi bas } \\
\text { tidak berbed } \\
\text { perlakuan tung } \\
\text { hayati yang di } \\
\text { rekomendasi } \mathrm{p}\end{array}$ & $\begin{array}{l}\text { nyata dengan } \\
\text { jal pupuk hayati dan } \\
\text { ombinasikan deng } \\
\text { tpuk kimia sintetik, }\end{array}$ & $\begin{array}{l}\text { (-) ini } \\
\text { pupuk } \\
25 \% \\
\text { ecuali }\end{array}$ \\
\hline
\end{tabular}


Bio Pf. Pemupukan kimia sintetik 100\% sesuai rekomendasi sendiri meningkatkan hasil hanya pada bobot umbi basah, namun tidak berbeda nyata bobot umbi kering dibandingkan dengan kontrol (-). Peningkatan bobot umbi basah dan kering secara signifikan umumnya terlihat pada perlakuan ketiga pupuk hayati yang dikombinasikan dengan pupuk kimia sintetik minimal $50 \%$ dari dosis rekomendasi dengan kisaran sebesar 54.55 - 100.9\% pada hasil umbi basah dan 75.43 - 138.21\% pada umbi kering dibandingkan tanpa pemupukan dan sebesar 5.77 32.69\% pada umbi basah dan 7.91 $32.65 \%$ pada umbi kering bila dibandingkan dengan tanaman bawang merah yang diberi perlakuan pupuk kimia sintetik $100 \%$ sesuai rekomendasi.

Tabel 4. Bobot umbi basah dan bobot umbi kering bawang merah pada berbagai perlakuan pupuk hayati.

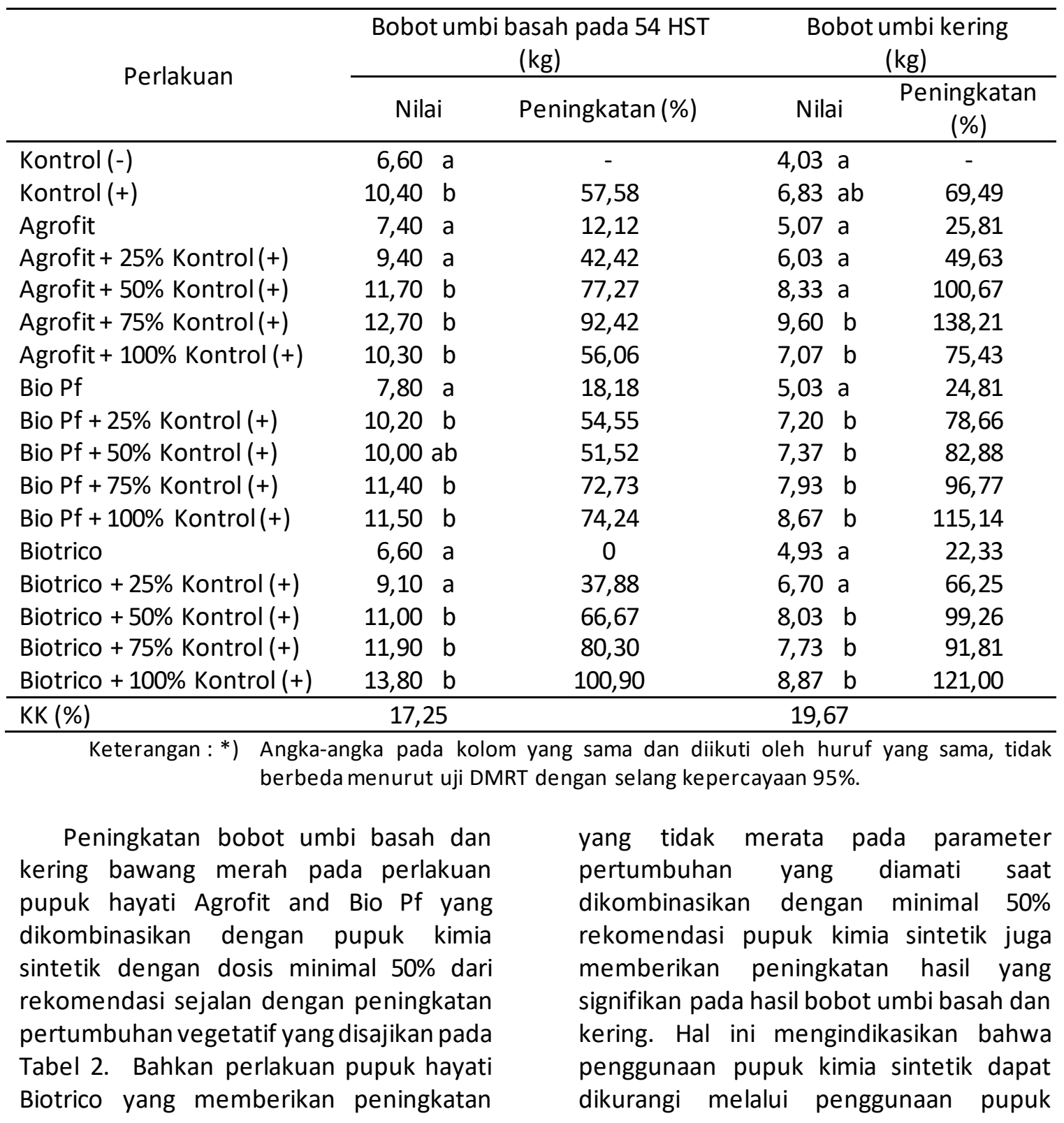


hayati yang mengandung mikrob pemacu pertumbuhan tanaman (Gunes et al., 2015). Pengurangan penggunaan pupuk kimia sintetik melalui aplikasi pupuk hayati juga berhasil dilakukan pada beberapa tanaman seperti tomat (Adesemoye, Torbert, \& Kloepper, 2009), lidah buaya (Meena, Narwal, Tara, \& Saharan, 2018), jahe (Dinesh et al., 2013), cabai (Batool \& Altaf, 2017), jagung (Poshtdar et al., 2012) dan tanaman lain dengan kisaran yang bervariasi.

Korelasi yang positif antara pertumbuhan vegetatif yang optimal dan peningkatan bobot umbi basah dan kering pada tanaman bawang merah yang diberi perlakuan kombinasi pupuk hayati dan pupuk kimia sintetik juga mengindikasikan bahwa mikrob pemacu pertumbuhan yang terkandung pada pupuk hayati mampu bersinergi dengan lingkungan tumbuh dan memberikan pengaruh terhadap peningkatan proses fisiologis tanaman dan akumulasi biomasa pada umbi bawang (Colo et al., 2014). Peningkatan kualitas pertumbuhan ini dimungkinkan berasal dari efek promotif pertumbuhan mikrob yang terkandung pada pupuk hayati dalam peningkatan penyerapan unsur hara akib at ketersediaan unsur hara yang meningkat dalam tanah (Nadeem et al., 2016; Yildirim et al., 2011) dan perlindungan tanaman terhadap serangan penyakit (Fernandes et al., 2018).

\section{Efektifitas relatif agronomi perlakuan pupuk hayati}

Perlakuan pupuk hayati dan kimia sintetik memberikan pengaruh yang bervariasi terhadap total biomasa tanaman bawang merah (Tabel 5). Tanaman bawang merah yang tidak diberi pupuk kimia sintetik dan hayati (kontrol (-) memberikan total biomasa terendah dengan nilai yang tidak berbeda nyata dengan kontrol (+) dan aplikasi tunggal ketiga jenis pupuk hayati yang dicoba. Penambahan pupuk kimia sintetik sebesar $25 \%$ dari rekomendasi memberikan peningkatkan total biomasa secara signifikan apabila dikombinasikan dengan Bio Pf dengan efektifitas relatif sebesar 113,07\%. Penambahan dosis pupuk kimia sintetik hingga 50\% pada perlakuan Bio PF justru memberikan selisih peningkatan efektifitas yang lebih kecil $(6,01 \%)$ dibandingkan dengan pupuk hayati Agrofit dan Biotrico yang memberikan selisih peningkatan efektifitas yang lebih besar, yaitu 41,44 dan 47,35\% walaupun total biomasa ketiga kombinasi perlakuan ini tidak berbeda nyata. Kondisi ini mengindikasikan bahwa pupuk hayati Bio Pf memberikan keefektifan total biomasa bawang merah lebih tinggi walaupun dikombinasikan dengan pupuk kimia sintetik pada dosis yang lebih rendah. Hal ini terlihat dari total biomasa yang tidak berbeda nyata dengan perlakuan pupuk hayati lain yang dikombinasikan dengan pupuk kimia sintetik dengan dosis yang sama maupun lebih tinggi.

Kefektifan pupuk hayati ditentukan oleh beberapa faktor diantaranya efektifitas mikrob yang terkandung pada pupuk hayati, tanaman dan lingkungan. Faktor lingkungan merupakan salah satu faktor yang mempunyai variasi yang tinggi dalam menentukan adaptibilitas dan aktifitas mikrob pupuk hayati yang diaplikasikan (Gouda et al., 2018). Salah satu fenomena yang sering ditemui adalah kondisi lingkungan yang optimal belum tentu memberikan efektifitas aktifitas mikrob menjadi lebih tinggi. Hal ini sejalan dengan pendapat Glick (2012) yang melaporkan bahwa keefektifan mikrob sering tidak jelas sekalipun tanaman dalam kondisi optimum dan tidak stress. Hal ini diduga disebabkan oleh faktor lain yang mempengaruhi kondisi mikroba yang diaplikasikan seperti kerapatan populasi 
mikrob setelah pupuk hayati diaplikasikan.

Berdasarkan Permentan nomor

261/kpts/sr.310/M/4/2019, 1 April 2019 tentang persyaratan teknis minimal pupuk organik, pupuk hayati, dan pembenah tanah, menyebutkan bahwa kandungan mikrob fungsional yang digunakan sebagai bahan aktifnya adalah : bakteri $\geq 1 \times 10^{8}$ $\mathrm{cfu} / \mathrm{g}$; Aktiomiset $1 \times 10^{6} \mathrm{spora} / \mathrm{m}$, dan cendawan $\geq 1 \times 10^{5} \mathrm{spora} / \mathrm{ml}$. Populasi dan kerapatan mikrob yang menjadi lebih tinggi setelah aplikasi pupuk hayati dapat menyebabkan kompetisi pada sesama mikrob yang diiokulasikan sehigga menurunkan daya hidup, daya saing dan perkembangan mikrob selanjutnya (Kenneth et al., 2018).

Tabel 5. Nilai efektifitas relatif agronomi (RAE) biomasa kering bawang merah pada perlakuan pupuk kimia sintetik dan pupuk hayati

\begin{tabular}{|c|c|c|}
\hline Perlakuan & $\begin{array}{c}\text { Biomasa hasil panen } \\
\text { bawang merah kering } \\
\left(\mathrm{t} \mathrm{ha}^{-1}\right)\end{array}$ & $\begin{array}{c}\text { RAE biomasa hasil panen } \\
\text { bawang merah kering } \\
(\%)\end{array}$ \\
\hline Kontrol (-) & $4,07 \quad a$ & 0 \\
\hline Kontrol (+) & $6,90 \mathrm{ab}$ & 100,00 \\
\hline Agrofit & 5,12 a & 37,10 \\
\hline Agrofit $+25 \%$ Kontrol $(+)$ & $6,09 \mathrm{a}$ & 71,38 \\
\hline Agrofit $+50 \%$ Kontrol $(+)$ & $8,41 \mathrm{~b}$ & 122,82 \\
\hline Agrofit + 75\% Kontrol (+) & $9,68 b$ & 198,23 \\
\hline Agrofit $+100 \%$ Kontrol $(+)$ & $7,14 b$ & 108,48 \\
\hline Bio Pf & $5,08 \mathrm{a}$ & 35,69 \\
\hline Bio Pf $+25 \%$ Kontrol $(+)$ & $7,27 \mathrm{~b}$ & 113,07 \\
\hline Bio Pf + 50\% Kontrol (+) & $7,44 \mathrm{~b}$ & 119,08 \\
\hline Bio Pf + 75\% Kontrol (+) & $8,01 \mathrm{~b}$ & 139,22 \\
\hline Bio Pf $+100 \%$ Kontrol $(+)$ & $8,76 \mathrm{~b}$ & 165,72 \\
\hline Biotrico & $4,98 \mathrm{a}$ & 32,16 \\
\hline Biotrico $+25 \%$ Kontrol (+) & $6,77 a$ & 95,41 \\
\hline Biotrico $+50 \%$ Kontrol $(+)$ & $8,11 b$ & 142,76 \\
\hline Biotrico + 75\% Kontrol (+) & $7,81 \mathrm{~b}$ & 132,16 \\
\hline Biotrico $+100 \%$ Kontrol $(+)$ & $8,96 \mathrm{~b}$ & 172,79 \\
\hline
\end{tabular}

KK (\%) 19,75

Keterangan: ${ }^{*}$ ) Angka-angka pada kolom yang sama dan diikuti oleh huruf yang sama, tidak berbeda menurut uji DMRT dengan selang kepercayaan $95 \%$.

\section{SIMPULAN}

Penggunaan pupuk hayati Agrofit, dan Bio Pf yang dikombinasikan dengan pupuk kimia sintetik $25 \%$ dari dosis rekomendasi memberikan perbaikan kualitas pertumbuhan, dan peningkatan bobot umbi kering dibandingkan dengan perlakuan kontrol. Nilai keefektifan relatif agronomi (RAE) dan penekanan terhadap serangan penyakit layu fusarium tertinggi ditunjukkan oleh kombinasi perlakuan pupuk hayati Bio Pf dengan pupuk kimia sintetik $25 \%$ dari dosis rekomendasi. RAE biomasa hasil panen kering layak jual dan persentase penekanan perlakuan terhadap fusarium pada perlakuan tersebut masingmasing adalah $113,07 \%$ dan $67,33 \%$.

\section{UCAPAN TERIMA KASIH}


Penulis mengucapkan terima kasih dan penghargaan yang setinggi-tingginya kepada Balai Penelitian Tanaman Hias, Pusat Penelitian dan Pengembangan Hortikultura, Pusat Penelitian dan Pengembangan Tanaman Pangan melalui Proyek Pupuk Hayati Unggulan Nasional (PHUN) TA. 2017, dan Badan Penelitian dan Pengembangan Pertanian atas dukungan fasilitas selama penelitian berlangsung. Penulis juga mengucapkan terima kasih kepada sdr. Muhidin, Ridwan Djaelani, Dadang Kusnandar, Ade Sulaiman dan semua pihak yang telah membantu dalam pengamatan dan pengumpulan data selama penelitian.

\section{DAFTAR PUSTAKA}

Adesemoye, A. O., Torbert, H. A., \& Kloepper, J. W. (2009). Plant growthpromoting rhizobacteria allow reduced application rates of chemical fertilizers. Microbial Ecology, 58(4), 921-929. https://doi.org/10.1007/s00248009-9531-y

Ahemad, M., \& Kibret, M. (2014). Mechanisms and applications of plant growth promoting rhizobacteria: Current perspective. Journal of King Saud University Science, 26(1), 1-20. https://doi.org/10.1016/j.jksus.2013. 05.001

Ahmed, A., \& Hasnain, S. (2014). Auxins as one of the factors of plant growth improvement by plant growth promoting rhizobacteria. Polish Journal of Microbiology, 63(3), 261-
266.

Badrudin, U., \& Jazilah, S. (2013). Analisis residu pestisida pada tanaman bawang merah (Allium ascalonicum L.) di Kabupaten Brebes. Jurnal Ilmu Pengetahuan dan Teknologi, 24(1), 75-86.

Batool, S., \& Altaf, M. A. (2017). Plant growth promoting rhizobacteria (PGPR) reduces application rates of fertilizers in chili (Capsicum frutescens L.) cultivation. Journal of Horticulture, 4(4), 1000215. https://doi.org/10.4172/23760354.1000215

Beneduzi, A., Ambrosini, A., \& Passaglia, L. M. P. (2012). Plant growthpromoting rhizobacteria (PGPR): Their potential as antagonists and biocontrol agents. Genetics and Molecular Biology, 35(4), 10441051.

Bunga, S. J., \& Lewar, Y. (2009). Produksi bawang merah akibat aplikasi pupuk organik cair fermentasi rumen sapi. Partner, 16(2), 41-49.

Chaudhry, M. Z., Naz, A. U., Nawaz, A. A. (2016). Colonization of plant growth promoting rhizobacteria (PGPR) on two different root systems. Pakistan Journal of Botany, 48(4), 1691-1696.

Colo, J., Jafari, T. I., Duric, S., Stamenov, D., \& Hamidovic, S. (2014). Plant growth promotion rhizobacteria in onion production. Polish Journal of Microbiology, 63(1), 83-88.

Compant, S., Clément, C., \& Sessitsch, A. (2010). Plant growth-promoting 
bacteria in the rhizo- and endosphere of plants: Their role, colonization, mechanisms involved and prospects for utilization. Soil Biology and Biochemistry, 42(5), 669-678.

https://doi.org/10.1016/j.soilbio.200 9.11.024

Damam, M., Kaloori, K., Gaddam, B., \& Kausar, R. (2016). Plant growth promoting substances (phytohormones) produced by rhizobacterial strains isolated from the rhizosphere of medicinal plants. International Journal of Pharmaceutical Science Review and Research, 37(1), 130-136.

Damayanti, R. S., Hanani, Y. D., \& Yunita, N. A. D. (2016). Hubungan penggunaan dan penanganan pestisida pada petanibawang merah terhdap residu pestisida dalam tanah di lahan pertanian Desa Wanasari Kecamatan Wanasari Kabupaten Brebes. Jurnal Kesehatan Masyarakat, 4(3), 879887.

Das, A. J., Kumar, M., \& Kumar, R. (2013). Plant growth promoting rhizobacteria (PGPR): An alternative of chemical fertilizer for sustainable, environment friendly agriculture. Research Journal of Agriculture and Forestry Sciences, 1(4), 21-23.

Das, I., \& Singh, A. P. (2014). Effect of PGPR and organic manures on soil properties of organically cultivated mungbean. The Bioscan, 9(1), 27-29.

Deden \& Umiyati, U. (2017). Pengaruh inokulasi Trichoderma sp. dan varietas bawang merah terhadap penyakit moler dan hasil tanaman bawang merah (Allium ascalonicum L.). Jurnal Kultivasi. 16(2), 340-348.

Dinesh, R., Anandaraj, M., Kumar, A., Srinivasan, V., Bini, Y. K., Subila, K. P., ... Hamza, S. (2013). Effects of plant growth-promoting rhizobacteria and NPK fertilizers on biochemical and microbial properties of soils under ginger (Zingiber officinale) cultivation. Agricultural Research, 2(4), 346-353. https://doi.org/10.1007/s40003013-0080-8

Fernandes, F., Abadi, A. L., \& Aini, L. Q. (2018). Utilization of plant growth promoting rhizobacteria (PGPR) in disease control important in plants onion (Allium ascalonicum L.). International Journal of Research Granthaalayah, 6(1), 126-136. https://doi.org/10.5281/zenodo.116 2718

Glick, B. R. (2012). Plant growth-promoting bacteria: Mechanisms and applications. Scientifica, (963401), 115. https://doi.org/10.6064/2012/96340 1

Gopinathan, R., \& Prakash, M. (2014). Isolation of plant growth promoting rhizobacteria (PGPR) from vermicompost and effect on growth of green gram (Vigna radiata L.). International Journal of Current Microbiology and Applied Science, 3(7), 1072-1081.

Gouda, S., Kerry, R. G., Das, G., 
Paramithiotis, S., Shin, H. S., \& Patra, J. K. (2018). Revitalization of plant growth promoting rhizobacteria for sustainable development in agriculture. Microbiological Research, 206, 131-140. https://doi.org/10.1016/j.micres.201 7.08.016

Gunes, A., Karagoz, K., Turan, M., Kotan, R., Yildirim, E., Cakmakci, R., \& Sahin, F. (2015). Fertilizer efficiency of some plant growth promoting rhizobacteria for plant growth. Research Journal of Soil Biology, 7(2), 28-45.

https://doi.org/10.3923/rjsb.2015.2

8.45

Gupta, G., Parihar, S. S., Ahirwar, N. K., Sheni, S. K., \& Singh, V. (2015). Plant growth promoting rhizobacteria (PGPR): Current and future prospects for development of sustainable agriculture. Journal of Microbial and Biochemical Technology, 7(2), 96102. https://doi.org/10.4172/19485948.1000188

Hanudin, \& Marwoto, B. (2003). Pengendalian layu bakteri dan akar gada pada tanaman tomat dan caisin menggunakan Pseudomomas flourescens. Jurnal Hortikultura, 13(1), 58-66.

Hanudin., (2007a). Kemangkusan Bacillus sp. dan Pseudomonas flourescens dalam formula cair untuk pengendalian Fusarium oxysporum $\mathrm{f}$. sp. dianthi pada tanaman anyelir. Jurnal Hortikultura (Edisi khusus), (1), 61-71.
Hanudin., (2007b). Pengaruh pH dan formula cair biopestisida Pseudomonas flourescens terhadap kemangkusan serta viabilitas Xanthomonas campestris pv. dieffenbachiae pada anthurium. Jurnal Hortikultura (Edisi khusus), (1), 72-78.

Hanudin, \& Marwoto, B. (2012). Prospek penggunaan mikroba antagonis sebagai agens pengendali hayati penyakit utama pada tanaman hias dan sayuran. Jurnal Penelitian dan Pengembangan Pertanian, 31(1), 813.

Harsanti, E. S., Martono, E., Sudibyakto, H. A., \& Sugiharto, E. (2015). Residu insektisida klorpirifos dalam tanah dan produksi bawang merah Allium ascalonicum L., di sentra produksi bawang merah di Kabupaten Bantul, Yogyakarta. Ecolab, 9(1), 26-34. https://doi.org/10.20886/jklh.2015.9 .1.26-35.

Hidayati. N, Rosawanti, P., \& Karyani, N. 2019. Perlakuan Trichoderma koningii dan Biourine terhadap pengendalian penyakit moler (Fusarium oxysporum), pertumbuhan dan hasil tanaman bawang merah (Allium ascalonicum L.) di tanah mineral. AGRIKAN. Jurnal Agribisnis Perikanan, 12(1), 83-92. https://doi.org/10.29239/j.agrikan.1 2.1.83-92.

Indrianingsih, W. A., Nisa, K., Wahono, S. K., Taufika, V., Rosyida, Damayanti, E., \& Maryana, R. (2007). Analisis residu pestisida dalam tanah dan umbi bawang merah di lahan pasir 
Sanden, Bantul, Yogyakarta dengan kromatografi gas. In Seminar Nasional Rekayasa Kimia Dan Proses 2007 ISSN: 1411-4216 (pp. 181-185).

Istina, I. N. (2016). Peningkatan produksi bawang merah melalui teknik pemupukan NPK. Jurnal Agro, 3(1), 36-42. https://doi.org/10.15575/810

Kaeni, E., Toekidjo, Subandiyah, S. (2014). Efektivitas suhu dan lama perendaman bibit empat kultivar bawang merah (Allium cepa L.) pada pertumbuhan dan daya tanggapnya terhadap penyakit moler. Vegetalika, 3(1), 53-65.

Kenneth, O. C., Nwadibe, E. C., Kalu, A. U., \& Unah, U. V. (2018). Plant growth promoting rhizobacteria (PGPR): A novel agent for sustainable food production. American Journal of Agricultural and Biological Sciences, 15(1), 1-20. https://doi.org/10.3844/ajabssp.201 8.

Khosravi, A., Zarei, M., \& Ronaghi, A. (2018). Effect of PGPR, phosphate sources and vermicompost on growth and nutrients uptake by lettuce in a calcareous soil. Journal of Plant Nutrition, 41(1), 80-89. https://doi.org/10.1080/01904167.2 017.1381727

Le Mire, G., Nguyen, M. L., Fassotte, B., du Jardin, P., Verheggen, F., Delaplace, P., \& Jijakli, M. H. (2016). Implementing plant biostimulants and biocontrol strategies in the agroecological management of cultivated ecosystems: A review.
Biotechnologie, Agronomie, Société et Environnement, 20(S1), 299-313.

Meena, Narwal, K., Tara, N., \& Saharan, B. S. (2018). Review on PGPR: An alternative for chemical fertilizers to promote growth in Aloe vera plants. International Journal of Current Microbiology Applied Science, 7(3), 3546-3551.

Miskiyah, \& Munarso, S. J. (2009). Kontaminasi residu pestisida pada cabai merah, selada, dan bawang merah (Studi kasus di Bandungan dan Brebes Jawa Tengah serta Cianjur Jawa Barat). Jurnal Hortikultura, 19(1), 101-111.

Nadeem, S. M., Naveed, M., Ayyub, M., Khan, M. Y., Ahmad, M., \& Zahir, Z. A. (2016). Potential, limitations and future prospects of Pseudomonas spp. for sustainable agriculture and environment: A Review. Soil Environment, 35(2), 106-145.

Nugroho, A. W., Hadiwiyono, Sudadi. 2015. Potensi jamur perakaran sebagai agens pengendali hayati penyakit moler (Fusarium oxysporum f. sp. cepae) pada bawang merah. Agrosains, 17(1), 4-8.

Ortega, R., Miralles, I., Domene, M. A., \& Soriano, M. (2017). Functions and applications of plant growth promoting bacteria (PGPR) in highly technified crops. Agricultural Research and Technology, 12(1), 1013. https://doi.org/10.19080/ARTOAJ.20 17.12.555837. 
Prakoso, E. B., Wiyatingsih, S., \& Nirwanto, H. (2016). Uji ketahanan berbagai kultivar bawang merah (Allium ascalonicum) terhadap infeksi penyakit moler (Fusarium oxysporum f.sp. cepae). Plumula, 5(1), 10-20.

Poshtdar, A., Siadat, S. A., Mashhadi, A. A., Moosavi, S. A., \& Hamdi, H. (2012). Comparison between application of PGPR bacteria and chemical fertilizers on quality and total silage yield of maize under different organic seed bed. International Journal of Agriculture and Crop Sciences, 4(11), 713-717.

Reed, S. C., Cleveland, C. C., \& Townsend, A. R. (2011). Functional ecology of free-living nitrogen fixation: A contemporary perspective. Annual Review of Ecology, Evolution, and Systematics, 42(1), 489-512. https://doi.org/10.1146/annurevecolsys-102710-145034.

Roquigny, R., Novinscak, A., Arseneault, T., Joly, D. L. \& Filion, M. (2018). Transcriptome alteration in Phytophthora infestans in response to phenazine-1- carboxylic acid production by Pseudomonas fluorescens strain LBUM223. BMC Genomics, $\quad 19, \quad 474$. https://doi.org/10.1186/s12864018-4852-1

Setiawan, A. F., \& Hadianto, A. (2014). Fluktuasi harga komoditas pangan dan dampaknya terhadap inflasi di Propinsi Banten. Jurnal Ekonomi Pertanian, Sumber Daya dan Lingkungan, 2, 81-97.
Sumarni, N., Rosliani, R., Basuki, R. S., \& Hilman, Y. (2013). Respons tanaman bawang merah terhadap pemupukan fosfat pada beberapa tingkat kesuburan lahan (status P-tanah). Jurnal Hortikultura, 22(2), 130-138. Retrieved from http://ejurnal.litbang.pertanian.go.id /index.php/jhort/article/view/739

Permentan Nomor 261/kpts/sr.310/M/4/ 2019, 1 April 2019 tentang persyaratan teknis minimal pupuk organik, pupuk hayati, dan pembenah tanah.

Vacheron, J., Desbrosses, G., Bouffaud, M. L., Touraine, B., Moënne-Loccoz, Y., Muller, D., ... Prigent-Combaret, C. (2013). Plant growth-promoting rhizobacteria and root system functioning. Frontiers in Plant Science, 4(356), 1-19. https://doi.org/10.3389/fpls.2013.00 356

Vejan, P., Abdullah, R., Khadiran, T., Ismail, S., \& Nasrulhaq Boyce, A. (2016) Role of plant growth promoting rhizobacteria in agricultural sustainability - A review. Molecules, 21(5), 1-17. https://doi.org/10.3390/molecules2 1050573.

Vivero, G. A. G. 2009. Resistance to Fusarium basal rot and response to arbuscular mycorrhizal fungi in Allium. Thesis, Wageningen University, 160p.

Wang, X., Mavrodi, D. V., Ke, L., Mavrodi, O. V., Yang, M., Thomashow, L. S., ... Zhang, J. (2015). Biocontrol and 
plant growth-promoting activity of rhizobacteria from chinese fields with contaminated soils. Microbial Biotechnology, 8(3), 404-418. https://doi.org/10.1111/17517915.12158

Wastra, A. R. (2015). Perlindungan produk pertanian menghadapi pasar bebas ASEAN (MEA) 2015. JurnalAgribisnis,
8(2), 111-124.

Yildirim, E., Karlidag, H., Turan, M., Dursun, A., \& Goktepe, F. (2011). Growth, nutrient uptake, and yield promotion of broccoli by plant growth promoting rhizobacteria with manure. HortScience, 46(6), 932936. 